\title{
Therapeutic Alliance: Using N-(2,3,4,5,6-Pentahydroxylhex-1-yl)-N- Dithiocarbamate- $L$-Isoleucine Disodium to Improve the Toxicity and Survival of Cisplatin Receiving Mice
}

\author{
Yuji Wang ${ }^{1}$, Ming Zhao ${ }^{1, *}$, Guohui Cui ${ }^{1}$, Chunying Cui ${ }^{1}$, Jingfang Ju ${ }^{2, *}$ and Shiqi Peng ${ }^{1, *}$ \\ ${ }^{1}$ College of Pharmaceutical Sciences, Capital Medical University, Beijing 100069, PR China and ${ }^{2}$ Mitchell Cancer \\ Research Institute, USA, 307 N. University Blvd, Mobile AL 36688-0002, USA
}

\begin{abstract}
To reduce the toxicity of cisplatin N-(2,3,4,5,6-pentahydroxylhex-1-yl)-N-dithiocarbamate- $L$-isoleucine disodium (GID) based therapeutic alliance is investigated. For the proliferation of $\mathrm{HepG}_{2}$, Hela, MES-SA, HL 60 and H1299 cells, $27 \mu \mathrm{M}$ of GID based therapeutic alliance gave comparable inhibition to cisplatin alone. For implanted tumor proliferation in mice, $1.667 \mu \mathrm{mol} / \mathrm{kg}$ of GID based therapeutic alliance gave higher inhibition than cisplatin alone. For cisplatin receiving mice, this therapeutic alliance effectively reduces the platinum accumulations in the organs but does not affect the platinum level in the tumor tissue. Comparing to cisplatin alone, this therapeutic alliance not only increases urea and fecal platinum levels but also increases urea excretion. All the observations imply that GID based therapeutic alliance is capable of reducing the toxicity and supporting the anti-tumor potency of cisplatin.
\end{abstract}

Key Words: Cisplatin, N-(2,3,4,5,6-Pentahydroxylhex-1-yl)-N-dithiocarbamate- $L$-isoleucine Disodium, Therapeutic Alliance, Anti-tumor, Toxicity.

\section{INTRODUCTION}

As one of the most potent chemotherapeutic antitumor drugs cisplatin is not only used against testicular and ovarian cancers but also used against bladder, cervical, head and neck, esophageal, and small cell lung cancer [1]. The wide antitumor actions of cisplatin are believed to be the results of the formation of the bifunctional platinum adducts of cisplatin with DNA and probably a reaction which depends on the initial formation of reactive aquated platinum (II) complexes is involved [2]. In cisplatin therapy however, some tumors have intrinsic resistance to cisplatin and develop acquired resistance [3]. On the other hand, nephrotoxicity has been emphasized as a dose-limiting factor $[4,5]$. Some processes and substances have been correlated with the nephrotoxicity, such as the oxidative pathways [6], human organic cation transporter 2 in renal proximal tubules [7], and gene expression [8]. The prevention of nephrotoxicity has been considered to be of clinically great importance in the cancer chemotherapy with cisplatin. The toxic effect of cisplatin has greatly hampered its application $[9,10]$, and a wide variety of agents such as selenium, vitamin $\mathrm{C}$, edaravone, cystone, erdosteine and tiopronin were co-administrated to decrease cisplatin-induced nephrotoxicity in the past few decades [1116]. In fact, the free radical damage mechanism is inherently related with the direct contribution of platinum itself. It is

*Address correspondence to these authors at the College of Pharmaceutical Sciences, Capital Medical University, Beijing 100069, P. R. China; Tel: 8610-8391-1528; Fax: 86-10-8391-1528; E-mail: sqpeng@bjmu.edu.cn; College of Pharmaceutical Sciences, Capital Medical University, Beijing 100069, P.R. China; Tel: 86-10-8391-1535; Fax: 86-10-8391-1528; E-mail: mingzhao@bjmu.edu.cn and Mitchell Cancer Institute-USA, 307 N. University Blvd, Mobile AL 36688-0002, USA; Tel: (251) 460-7393; Fax: (251) 460-6994; E-mail: jju@usouthal.edu usually considered that in the human body a series of targets other than DNA are able to bind with ciaplatin and lead to multiple effects excluding undesirable effects. For example, among the binding cisplatin only $5 \%$ to $10 \%$ of covalently bound cell-associated cisplatin is found in DNA, whereas $75 \%$ to $85 \%$ of cisplatin binds to proteins $[17,18]$. As the first step of the accumulation inside cells, cisplatin could bind to phospholipids and phosphatidylserine of the cell membrane [19]. On the other hand, approaching cytoplasm cisplatin may react with the soft nucleophilic sites of cytoskeletal microfilaments, thiol-containing peptides, proteins and RNA [20]. Same as cisplatin-induced DNA damage of tumor cells, cisplatin-induced DNA or protein damage may directly or indirectly promote normal cells to programmed death $[21,22]$. With regard to normal tissues and organs, cisplatin-induced DNA and protein damage is a key step to induce cisplatin toxonosis based disorders such as kidney, intestines, stomach, marrow, nerve and ear disorders. As an immediate result a preliminary treatments of cisplatin may cause $33 \%$ patients suffer from kidney damage. While continuous treatments of cisplatin the incidence of kidney damage of patients may clamber to $75 \%[23,24]$. This status attracts a lot of interests dealing with platinum itself to lower the nephrotoxicity.

The facts that elevated levels of heavy metals may lead to impairments of the central nervous system such as delayed cognitive development, reduced IQ scores, impaired hearing, and neurobehavioral deficiencies prompt us pay a great deal of interests to develop antagonists of lead and cadmium intoxication. Our previous studies demonstrated that as heavy metal decorporation substances glycosylamines and glycosyldithiocarbamate- $L$-amino acids are highly potency and 
hypotoxicity [25-28]. The similarity of lead, cadmium and platinum intoxication encourages us preparing 20 glycosyldithiocarbamate- $L$-amino acid disodiums (Fig. 1) as the partners of cisplatin in their therapeutic alliance to improve anticancer therapy.

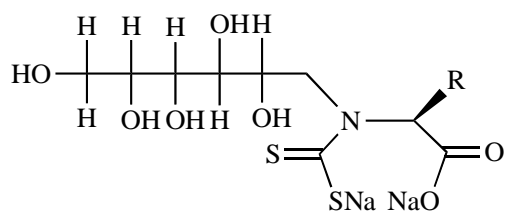

Fig. (1). Formula of glycosyldithiocarbamate- $L$-amino acid disodiums, wherein $\mathrm{R}$ represents the side chain of $L$-amino acids, for GID $\mathrm{R}=\mathrm{CH}\left(\mathrm{CH}_{3}\right) \mathrm{CH}_{2} \mathrm{CH}_{3}$.

The preliminary screening explored that via therapeutic alliance 20 glycosyldithiocarbamate- $L$-amino acid disodiums were able to reduce the organ platinum levels, toxicity and mortality of cisplatin receiving mice. The detailed in vitro and in vivo biological activity data of these 20 glycosyldithiocarbamate- $L$-amino acid disodiums from the therapeutic alliance will be reported elsewhere. In the present paper we select GID, one of the most potency compounds, to explore the benefit of this therapeutic alliance.

\section{MATERIALS AND METHODS}

\subsection{Reagents and Instruments in Chemical Synthesis}

All the reactions were carried out under nitrogen (1 bar). ${ }^{1} \mathrm{H}(300$ and $500 \mathrm{M} \mathrm{Hz})$ and ${ }^{13} \mathrm{C}(75$ and $125 \mathrm{M} \mathrm{Hz}) \mathrm{NMR}$ spectra were recorded on Bruker AMX-300 and AMX-500 spectrometers for solution of $\mathrm{D}_{2} \mathrm{O}, \mathrm{DMSO}-\mathrm{d}_{6}$, or $\mathrm{CDCl}_{3}$ with tetramethylsilane as internal standard. IR spectra were recorded on a Perkin-Elmer 983 instrument. FAB/MS was determined on VG-ZAB-MS and TOF-MS was recorded on MDS SCIEX QSTAR. Melting points were measured on a XT5 hot stage microscope (Beijing key electro-optic factory). Optical rotations were determined with a Jasco P-1020 Polarimeter at $20^{\circ} \mathrm{C}$. All $L$-amino acids and $\alpha$ - $D$-glucose were purchased from China Biochemical Corp. TLC was made with Qingdao silica gel GF254. Chromatography was performed with Qingdao silica gel $\mathrm{H}_{60}$ or Sephadex- $\mathrm{LH}_{20}$. All solvents were distilled and dried before use by reference to literature procedures. Cisplatin (Platinol, crystalline) was purchased from Qilu Pharmaceutical Co. Ltd, China.

\subsection{Preparing GID}

To the solution of $0.40 \mathrm{~g}(10 \mathrm{mmol})$ of $\mathrm{NaOH}$ in $3 \mathrm{ml}$ of methanol/water $(1: 1) 1.31 \mathrm{~g}(10 \mathrm{mmol})$ of $L$-Ile was added. The mixture was stirred at room temperature for $20 \mathrm{~min}$ and $L$-Ile was completely dissolved. Then to the solution, $1.80 \mathrm{~g}$ (10 mmol) of $\alpha$ - $D$-glucose was added. The mixture was stirred at room temperature until $\alpha$ - $D$-glucose was completely dissolved. Under the protection of argon gas the solution was stirred at $50-60^{\circ} \mathrm{C}$ for $5 \mathrm{~h}$ and then in situ treated with $1.62 \mathrm{~g}(30 \mathrm{mmol})$ of sodium borohydrate at room temperature for $96 \mathrm{~h}$. The reaction mixture was cooled to $0^{\circ} \mathrm{C}$ and adjusted to $\mathrm{pH} 2.5$ by adding concentrated hydrochloric acid. The formed precipitates were removed by filtration and the filtrate was evaporated under vacuum. The residue was diluted with anhydrous ethanol and the formed precipitates were removed by filtration. This procedure was repeated for 5 times and the residue was dissolved in $10 \mathrm{ml}$ of water. The solution was loaded on the column of acidic ion exchange resin and eluted with $3 \%$ aqueous solution of N-methylmorpholine to give $1239 \mathrm{mg}(42 \%)$ of $\mathrm{N}-(2,3,4,5,6$-pentahydroxylhexyl)- $L$-isoleucine as a colorless powder (Mp 228$230^{\circ} \mathrm{C}$, ESI (m/e) $\left.296[\mathrm{M}+\mathrm{H}]^{+}\right)$.

The suspension of $295 \mathrm{mg}(1 \mathrm{mmol})$ of $\mathrm{N}-(2,3,4,5,6-$ pentahydroxylhexyl)- $L$-isoleucine in $5 \mathrm{ml}$ of water was stirred at $0^{\circ} \mathrm{C}$ for $10 \mathrm{~min}$ and then $40 \mathrm{mg}(1 \mathrm{mmol})$ of $\mathrm{NaOH}$ was added to form a clean solution. To this solution a solution of $304 \mathrm{mg}$ ( $4 \mathrm{mmol})$ of $\mathrm{CS}_{2}, 40 \mathrm{mg}(1 \mathrm{mmol})$ of $\mathrm{NaOH}$, $0.4 \mathrm{ml}$ of dioxane and $2 \mathrm{ml}$ of water were added. The reaction mixture was stirred at $0^{\circ} \mathrm{C}$ for $5 \mathrm{~min}$ and $4 \mathrm{ml}$ of the solution of $202 \mathrm{mg}$ ( $2 \mathrm{mmol})$ of triethylamine in $4 \mathrm{ml}$ of tetrahydrofuran was added. The reaction mixture was stirred at $0^{\circ} \mathrm{C}$ for $24 \mathrm{~h}$. The reaction mixture was filtered and the filtrate was evaporated under vacuum. The residue was crystallized in aqueous acetone to give $367 \mathrm{mg}$ (88\%) of GID as a yellow powder (ESI-MS (m/e) $417[\mathrm{M}+\mathrm{H}]^{+}$). Its HPLC purity was more than $98 \%$.

\subsection{In Vitro Anti-proliferation Assay of the Therapeutic Alliance}

In the evaluation of the anti-proliferation, human carcinoma cell lung carcinoma (H1299), liver carcinoma (Hep$\mathrm{G}_{2}$ ), cervical carcinoma (Hela), immature granulocyte leukemia $\left(\mathrm{HL}_{60}\right)$ and doxorubicin sensitive human sarcoma (MES-SA) cells were cultivated at $37^{\circ} \mathrm{C}$ in $75 \mathrm{~cm}^{2}$ flask, to which $12 \mathrm{ml}$ of RPMI1640 (Gibco Laboratories, Santa Clara, CA, USA) containing 10\% fetal calf serum (Gibco Laboratories) was added. The cells were grown at a density of $1 \times 10^{5}$ cells $/ \mathrm{ml}$ and incubated in humidified air with $5 \% \mathrm{CO}_{2}$. The antibiotics were administered in the concentrations of $100 \mathrm{U} /$ $\mathrm{ml}$ and $100 \mu \mathrm{g} / \mathrm{ml}$ for penicillin and streptomycin, respectively.

The proliferations of H1299, HepG2, Hela, $\mathrm{HL}_{60}$, and MES-SA cells were determined using the colorimetric MTT assay as described previously (Mosmann, 1983). Briefly, cells were seeded at a density of $5 \times 10^{4}$ cells/well in a $100 \mu \mathrm{l}$ volume of the medium in 96-well plates (Corning, NY, USA). As the treating group to each well of 9 wells $12.5 \mu \mathrm{l}$ of cisplatin in NS (final concentration, $333 \mu \mathrm{M}$ ) and $12.5 \mu \mathrm{l}$ of GID (final concentrations from $27 \mu \mathrm{M}$ to $16667 \mu \mathrm{M}$ ) in NS were added, as the positive control to each well of 9 wells 25 $\mu \mathrm{l}$ of cisplatin in NS (final concentration, $333 \mu \mathrm{M}$ ) was added, as the negative control $25 \mu \mathrm{l}$ of NS was added. The 96-well plates were incubated for $48 \mathrm{~h}$, centifuged at $2000 \mathrm{r} / \mathrm{min}$ for $10 \mathrm{~min}$ and the supernatant was aspirated. To each well's residue $20 \mu \mathrm{l}$ of MTT ( $5 \mathrm{~g} / \mathrm{l})$ was added. The 96well plates were incubated at $37^{\circ} \mathrm{C}$ for $4 \mathrm{~h}$ and the supernatant was aspirated. To each well's residue $100 \mu \mathrm{l}$ of DMSO was added and then shaken for $8 \mathrm{~min}$. The absorbance was measured at $570 \mathrm{~nm}$ (reference at $630 \mathrm{~nm}$ ) on a 96-well microplate reader (Mode 680, Bio-Rad).

\subsection{In Vivo Anti-tumor Assay for the Therapeutic Alli- ance}

Male ICR mice (Experimental Animal Center of Capital Medical University) approximately 10-12 week old were maintained in individual stainless steel wire bottom cages 
suspended on racks. The mice were kept under carefully controlled conditions of 12-h light/dark cycle, $21^{\circ} \mathrm{C}$ and $50 \pm 20 \%$ relative humidity. The mice were acclimated to this environment for 4-7 days prior to the start of the study. S180 was used transplanting the mice to form solid tumors and given by subcutaneous injection. S180 cells for initiation of subcutaneous tumors were obtained from the ascitic form of the tumors in mice, which were serially transplanted once per week. Subcutaneous tumors were implanted by injecting $0.2 \mathrm{ml}$ of $0.9 \%$ saline containing $4 \times 10^{6}$ viable tumor cells under the skin on the right oxter. Twenty-four hours after implantation, the mice (10 per group) were randomly divided into experimental groups. The mice of the positive control group were given a daily i.p injection of $16.67 \mu \mathrm{mol} / \mathrm{kg}$ of cisplatin (Platinol, Qilu Pharmaceutical Factory, China) in $0.2 \mathrm{ml}$ of $0.9 \%$ saline for ten consecutive days. The mice of the negative control group were given a daily i.p injection of $0.2 \mathrm{ml}$ of $0.9 \%$ saline for ten consecutive days. The mice of the treatment groups were given a daily i.p injection of $16.67 \mu \mathrm{mol} / \mathrm{kg}$ of cisplatin in $0.2 \mathrm{ml}$ of $0.9 \%$ saline and 16.67 $\mu \mathrm{mol} / \mathrm{kg}$ of GID in $0.2 \mathrm{ml}$ of $0.9 \%$ saline for ten consecutive days. On the first day, $2 \mathrm{~h}$ after the administration the urine samples of each group were continually collected for $5 \mathrm{~h}$ and the fecal samples of each group were continually collected for $24 \mathrm{~h}$. Twenty-four hours after the last administration, all mice were weighed and blood was drawn from the eye orbit. Then the mice were sacrificed by diethyl ether anesthesia and dissected to immediately obtain and weigh the tumor, liver, kidney, brain, spleen, heart and left femur samples. All of the biosamples were digested in $\mathrm{HClO}_{4}$ and $\mathrm{HNO}_{3}(1: 3)$ on a heating block, dried at $80^{\circ} \mathrm{C}$, re-dissolved in $1 \%$ nitric acid to determine the content of platinum using a Varian Spectr AA-40 atomic absorption spectrometer in the graphite furnace.

The studies with mice described above were performed according to a protocol reviewed and approved by the ethics committee of Capital Medical University. The committee ensures that the welfare of the animals is maintained in accordance to the requirements of the Animal Welfare Act and according to the Guide for Care and Use of Laboratory Animals.

The data obtained from the assays of Items $\mathbf{2 . 3}$ to $\mathbf{2 . 5}$ were presented as mean values \pm SEM and the statistical analysis of the data was carried out using ANOVA test, $\mathrm{P}<0.05$ was considered significant.

\section{RESULTS AND DISCUSSION}

\subsection{Two-step-procedure Preparing GID}

The synthetic route of GID included a two-step-procedure. The first step related to the preparation of $\mathrm{N}-(2,3,4,5,6-$ pentahydroxylhexyl)- $L$-isoleucine via (i) condensing glucose and $L$-isoleucine, (ii) reducing the Schiff base and (iii) acidifying the sodium carboxylates. The obvious features of this simplified one-pot-three-step synthesis are that it can be applied to a variety of natural amino acids, need no tedious separation steps and provided N-(2,3,4,5,6-pentahydroxylhexyl)- $L$-isoleucine in acceptable total yield (42\%).

The second step related to the preparation of GID via (i) coupling $\mathrm{N}-(2,3,4,5,6$-pentahydroxylhexyl)- $L$-isoleucine and disulfide, and (ii) neutralizing N-(2,3,4,5,6-pentahyd-
roxylhexyl)-N-dithiocarbamate- $L$-isoleucine with sodium hydroxide. As same as the one-pot-three-step procedure mentioned above this one-pot-two-step synthesis have also obvious features such as it can be applied to a variety of $\mathrm{N}$ (2,3,4,5,6-pentahydroxylhexyl)- $L$-amino acids, need no tedious separation steps and provided GID in high total yield $(88 \%)$.

\subsection{Effect of GID on the In Vitro Anti-proliferation Ac- tivity of Cisplatin}

In the in vitro assays, the effect of GID as a partner of cisplatin in the therapeutic alliance on the in vitro antiproliferation activity of cicplatin was evaluated using $\mathrm{HL}_{60}$, $\mathrm{H} 1299, \mathrm{HepG}_{2}$, Hela and MES-SA cells. The growth inhibition values are listed in Table $\mathbf{1}$. The data indicate that cisplatin induced growth inhibition to all five cell lines was affected by GID in a dose dependent manner. It was particularly noticed that $27 \mu \mathrm{M}$ of GID remained cisplatin induced growth inhibition to $\mathrm{HepG}_{2}$, Hela, and MES-SA cells, and enhanced cisplatin induced growth inhibition to $\mathrm{HL}_{60}$ and H1299 cells. With the increase of GID's concentration cisplatin induced growth inhibitions to all five cell lines were lowered significantly. In the mentioned MTT assay cisplatin was directly mixed with GID. It is clear that cisplatin is a coordination complex and GID is a chelating agent. Treating cisplatin directly with high concentration of GID may result in decomposition of cisplatin. This should be responsible for higher concentration of GID lowering cisplatin induced growth inhibition to five cell lines.

Table 1. Effect of Therapeutic Alliance of Cp with GID on the Growth of Carcinoma Cells ${ }^{\text {a }}$

\begin{tabular}{|c|c|c|c|c|c|c|}
\hline \multirow{2}{*}{$\begin{array}{c}\text { Cell } \\
\text { Lines }\end{array}$} & \multicolumn{6}{|c|}{$\%$ Inhibition of $333 \mu \mathrm{M} \mathrm{Cp}$ with } \\
\hline & $\begin{array}{l}0 \mu \mathrm{M} \\
\text { GID }\end{array}$ & $\begin{array}{c}27 \mu \mathrm{M} \\
\text { GID }\end{array}$ & $\begin{array}{c}133 \mu \mathrm{M} \\
\text { GID }\end{array}$ & $\begin{array}{c}667 \mu M \\
\text { GID }\end{array}$ & $\begin{array}{c}3333 \mu \mathrm{M} \\
\text { GID }\end{array}$ & $\begin{array}{c}16667 \mu \mathrm{M} \\
\text { GID }\end{array}$ \\
\hline $\mathrm{HL}_{60}$ & $\begin{array}{l}75.05 \\
\pm 2.94\end{array}$ & $\begin{array}{c}81.87 \\
\pm 1.50^{\mathrm{b}}\end{array}$ & $\begin{array}{l}77.87 \\
\pm 1.28\end{array}$ & $\begin{array}{l}74.99 \\
\pm 1.97\end{array}$ & $\begin{array}{l}54.70 \\
\pm 1.33\end{array}$ & $\begin{array}{l}15.55 \\
\pm 6.21\end{array}$ \\
\hline H1299 & $\begin{array}{l}76.68 \\
\pm 0.94\end{array}$ & $\begin{array}{c}82.54 \\
\pm 0.94^{\mathrm{b}}\end{array}$ & $\begin{array}{l}77.81 \\
\pm 1.92\end{array}$ & $\begin{array}{l}76.18 \\
\pm 1.31\end{array}$ & $\begin{array}{l}53.36 \\
\pm 1.14\end{array}$ & $\begin{array}{l}14.34 \\
\pm 6.29\end{array}$ \\
\hline $\mathrm{HepG}_{2}$ & $\begin{array}{l}80.68 \\
\pm 1.72\end{array}$ & $\begin{array}{l}81.69 \\
\pm 2.33^{\mathrm{c}}\end{array}$ & $\begin{array}{l}69.93 \\
\pm 1.94\end{array}$ & $\begin{array}{l}54.72 \\
\pm 4.22\end{array}$ & $\begin{array}{l}18.83 \\
\pm 2.79\end{array}$ & $\begin{array}{l}12.51 \\
\pm 5.03\end{array}$ \\
\hline Hela & $\begin{array}{l}77.97 \\
\pm 1.55\end{array}$ & $\begin{array}{r}78.97 \\
\pm 1.78^{\mathrm{c}}\end{array}$ & $\begin{array}{l}66.96 \\
\pm 2.05\end{array}$ & $\begin{array}{l}54.94 \\
\pm 2.59\end{array}$ & $\begin{array}{l}18.90 \\
\pm 4.21\end{array}$ & $\begin{array}{l}12.89 \\
\pm 6.89\end{array}$ \\
\hline MES-SA & $\begin{array}{l}79.93 \\
\pm 1.60\end{array}$ & $\begin{array}{r}79.00 \\
\pm 2.23^{\mathrm{c}}\end{array}$ & $\begin{array}{l}65.00 \\
\pm 3.25\end{array}$ & $\begin{array}{l}38.43 \\
\pm 5.31\end{array}$ & $\begin{array}{l}21.72 \\
\pm 4.29\end{array}$ & $\begin{array}{l}11.68 \\
\pm 4.35\end{array}$ \\
\hline
\end{tabular}

a) $\quad \mathrm{Cp}=$ Cisplatin; $\quad \mathrm{GID}=\mathrm{N}-(2,3,4,5,6$-pentahydroxylhex-1-yl)-N-dithiocarbamate- $L$ isoleucine disodium; $\mathrm{n}=9$; $\mathrm{b}$ ) Compared to $\mathrm{Cp}$ alone $\mathrm{p}<0.01$, c) Compared to $\mathrm{Cp}$ alone $\mathrm{p}>0.05$.

\subsection{Effect of GID on the In Vivo Anti-tumor Activity of Cisplatin}

In the in vivo assays, the effect of GID as a partner of cisplatin in the therapeutic alliance on the in vivo anti-tumor activity of cicplatin was evaluated using S180 mice and the tumor weights are listed in Table 2. Giving a daily i.p injection of the solution of $16.67 \mu \mathrm{mol} / \mathrm{kg}$ of cisplatin in $0.2 \mathrm{ml}$ of 
NS for ten consecutive days the tumor weight was significantly reduced from $1412.20 \pm 247.79 \mathrm{mg}$ for NS receiving mice to $196.05 \pm 42.08 \mathrm{mg}$ for cisplatin receiving mice $(p<0.01)$. Giving a daily i.p injection of the solution of $16.67 \mu \mathrm{mol} / \mathrm{kg}$ of cisplatin in $0.2 \mathrm{ml}$ of NS and the solution of $16.67 \mu \mathrm{mol} / \mathrm{kg}$ of GID in $0.2 \mathrm{ml}$ of NS for ten consecutive days the tumor weight was significantly reduced from $1412.20 \pm 247.79 \mathrm{mg}$ of NS receiving mice to $156.40 \pm 40.59$ $\mathrm{mg}$ of therapeutic alliance mice $(\mathrm{p}<0.01)$. At the dose of $16.67 \mu \mathrm{mol} / \mathrm{kg}$ GID significantly enhance the anti-tumor activity of cisplatin. This enhanced action was accompanied by lowering the tumor weight from $196.05 \pm 42.08 \mathrm{mg}$ of cisplatin alone receiving mice to $156.40 \pm 40.59 \mathrm{mg}$ of therapeutic alliance mice, or accompanied by increasing inhibition from $86.48 \%$ for cisplatin alone receiving mice to $88.93 \%$ for therapeutic alliance mice.

Table 2. Effects of the Therapeutic Alliance on Tumor Weight of S180 Mice ${ }^{\text {a }}$

\begin{tabular}{|c|c|c|}
\hline Group & Tumor Weight $(\mathbf{m g})$ & \% Inhibition \\
\hline \hline NS & $1412.20 \pm 247.79$ & 0 \\
\hline Cp alone & $196.05 \pm 42.08^{\mathrm{b}}$ & 86.48 \\
\hline Cp + GID & $156.40 \pm 40.59^{\mathrm{c}}$ & 88.93 \\
\hline
\end{tabular}

a) $\mathrm{Cp}=$ Cisplatin; $\mathrm{GID}=\mathrm{N}-(2,3,4,5,6$-pentahydroxylhex-1-yl)-N-dithiocarbamate- $L$-isoleucine disodium; Tumor weight is expressed by $\bar{x} \pm \mathrm{SD} \mathrm{mg}$, NS (normal saline) $=$ vehicle, $\mathrm{n}=10 ; \mathrm{b}$ ) Compared to NS $\mathrm{p}<0.01$; c) Compared to NS $\mathrm{p}<0.01$ and to Cp alone $\mathrm{p}<0.05$.

\subsection{In Vivo Anti-tumor Action of GID Alone}

To evaluate the possibility of GID alone as anti-tumor agent, it was given to S180 mice a daily i.p injection (dose, $84 \mu \mathrm{mol} / \mathrm{kg}$ in $0.2 \mathrm{ml}$ of NS) for ten consecutive days and the tumor weight was recorded. It was found that the tumor weight was $1201.56 \pm 238.08 \mathrm{mg}$ (compare to $1412.20 \pm 247$. $79 \mathrm{mg}$ of NS receiving mice, $\mathrm{p}>0.05)$. This observation means that GID itself possesses 4 no obvious anti-tumor activity.

\subsection{Effect of GID on the Tumor Platinum Level of Cis- platin Receiving Mice}

For desirable cisplatin therapy a sufficient dose of tumor cisplatin is critical. To examine the effect of the therapeutic alliance on tumor cisplatin the platinum level of S180 mice's tumor was determined. Following the procedure of item 2.4 the mice were treated, the tumors were digested and the platinum contents were determined. After treatment for ten consecutive days the contents of platinum were $5.29 \pm 1.62 \mu \mathrm{g}$ and $4.38 \pm 0.79 \mu \mathrm{g}$ of platinum per $\mathrm{g}$ of tumor for cisplatin alone receiving mice and the therapeutic alliance mice, respectively (Table 3). No significant difference is noticed between the two values $(p>0.05)$ and thus the therapeutic alliance did not decrease the tumor platinum level.

\subsection{Effect of GID on the Organ Platinum Level of Cis- platin Receiving Mice}

The side effects of cisplatin therapy are the general result of platinum accumulation in organs. To examine the effect of therapeutic alliance on platinum accumulation the platinum levels of spleens, kidneys, livers, brains and hearts of S180 mice were determined. Following the procedure of item 2.4 the mice were treated, the spleens, kidneys, livers, brains and hearts were digested, the platinum contents were determined and the data are listed in Table 3. It was found that in per $\mathrm{g}$ of organ the platinum contents of cisplatin alone receiving mice were significantly higher than those of the therapeutic alliance mice, meaning that all the organ platinum levels were significantly decreased by GID.

Table 3. Effects of the Therapeutic Alliance on Organ and Tumor Platinum Levels ${ }^{a}$

\begin{tabular}{|c|c|c|c|}
\hline \multirow{2}{*}{ Group } & \multicolumn{3}{|c|}{ Platinum Level in Following Organs } \\
\cline { 2 - 4 } & Cp Alone & Cp+ GID & NS \\
\hline \hline Spleen & $6.05 \pm 1.35$ & $4.12 \pm 0.98^{\mathrm{b}}$ & 0 \\
\hline Kidney & $12.41 \pm 2.67$ & $4.96 \pm 1.36^{\mathrm{c}}$ & 0 \\
\hline Liver & $10.68 \pm 1.86$ & $5.96 \pm 0.72^{\mathrm{c}}$ & 0 \\
\hline Brain & $0.70 \pm 0.22$ & $0.23 \pm 0.09^{\mathrm{c}}$ & 0 \\
\hline Heart & $1.58 \pm 0.59$ & $0.35 \pm 0.07^{\mathrm{c}}$ & 0 \\
\hline Tumor & $5.29 \pm 1.62$ & $4.38 \pm 0.79^{\mathrm{d}}$ & 0 \\
\hline
\end{tabular}

a) $\mathrm{Cp}=$ Cisplatin; $\mathrm{GID}=\mathrm{N}-(2,3,4,5,6$-pentahydroxylhex-1-yl)-N-dithiocarbamate- $L$-isoleucine disodium; Organ platinum is expressed by $\bar{x} \pm \mathrm{SD} \mu \mathrm{g}$ platinum per $\mathrm{g}$ of organ; $\mathrm{n}=10$; b) Compared to Cp alone $\mathrm{p}<0.01$, c) Compared to Cp alone $\mathrm{p}<0.001$, d) Compared to $\mathrm{Cp}$ alone $\mathrm{p}>0.05$.

\subsection{Effect of GID on Urea, Fecal and Blood Platinum of Cisplatin Receiving Mice}

To compare the urea, fecal and blood platinum of cisplatin alone receiving mice and the therapeutic alliance mice the corresponding platinum levels were determined. Following the procedure of item 2.4 the mice were treated, the urea, fecal and blood were digested, the platinum contents were determined and the data are listed in Table 4. It was found that the platinum contents of the urea and fecal of cisplatin alone receiving mice were significantly higher than those of the therapeutic alliance mice. On the other hand the platinum content of the blood of cisplatin alone receiving mice was significantly lower than that of the therapeutic alliance mice. The observations indicate that via the therapeutic alliance the platinum accumulation in the mouse bodies resulted from cisplatin therapy can be effectively avoided via excretion of urea and fecal.

\subsection{Effect of GID on Urea Quantity of Cisplatin Receiv- ing Mice}

To examine the effect of the therapeutic alliance on the urea quantity the urea quantity of cisplatin alone receiving mice and the therapeutic alliance mice was compared. Following the procedure of item 2.4 the mice were treated, the urea was collected and the urea quantity was determined. The data indicate that the urea quantity $(1.35 \pm 0.35 \mathrm{ml})$ of NS receiving mice is significantly higher $(\mathrm{n}=10, \mathrm{p}<0.001)$ than that $(0.58 \pm 0.19 \mathrm{ml})$ of $16.67 \mu \mathrm{mol} / \mathrm{kg}$ of cisplatin alone receiving mice. On the other hand however the urea quantities 
$(2.26 \pm 0.21 \mathrm{ml})$ of the therapeutic alliance mice is significantly higher $(n=10, p<0.001)$ than that of NS and cisplatin alone receiving mice. This observation suggests that comparing to normal mice cisplatin treatment decreases urination and the therapeutic alliance increases urination. This observation also indicates that via the therapeutic alliance the platinum accumulation in the mouse bodies resulted from cisplatin therapy can be effectively avoided via increasing urination.

Table 4. Effects of the Therapeutic Alliance on Urea, Fecal and Blood Platinum ${ }^{\text {a }}$

\begin{tabular}{|c|c|c|c|}
\hline Group & $\begin{array}{c}\text { Urea } \\
\text { Platinum }\end{array}$ & $\begin{array}{c}\text { Fecal } \\
\text { Platinum }\end{array}$ & $\begin{array}{c}\text { Blood } \\
\text { Platinum }\end{array}$ \\
\hline \hline NS & 0 & 0 & 0 \\
\hline Cp alone & $26.78 \pm 3.26$ & $8.36 \pm 2.25$ & $6.19 \pm 1.11$ \\
\hline Cp + GID & $31.24 \pm 3.56^{\mathrm{b}}$ & $10.62 \pm 2.26^{\mathrm{b}}$ & $1.39 \pm 0.42^{\mathrm{c}}$ \\
\hline
\end{tabular}

a) $\mathrm{Cp}=$ cisplatin; $\mathrm{GID}=\mathrm{N}-(2,3,4,5,6$-pentahydroxylhex-1-yl)-N-dithiocarbamate- $L$-isoleucine disodium; The urea and fecal platinum is expressed by $\bar{x} \pm \mathrm{SD} \mu \mathrm{g}$ platinum per $\mathrm{g}$ of urea and fecal; blood platinum is expressed by $\bar{x} \pm \mathrm{SD} \mu \mathrm{g}$ platinum per $\mathrm{ml}$ of blood, $\mathrm{n}=10$; b) Compared to cisplatin alone $\mathrm{p}<0.05$; c) Compared to cisplatin alone, $\mathrm{p}<0.001$.

\subsection{Effect of GID on Body and Organ Weights of Cis- platin Receiving Mice}

One of visible results of cisplatin toxonosis related organ damage should be tissue necrosis, and total result of organ damage should be body emaciation. To evaluate the effect of the therapeutic alliance on cisplatin toxonosis related organ damage the body weights, absolute organ weights and relative organ weights of S180 mice were measured. Following the procedure of item $\mathbf{2 . 4}$ the mice were treated, the weights of the mice body, kidney, brain, spleen, heart, liver and left femur were determined. It was found that the body weight of NS, cisplatin alone and therapeutic alliance treated mice were $30.62 \pm 2.22 \mathrm{~g}, 20.44 \pm 3.40 \mathrm{~g}$ and $26.22 \pm 2.49 \mathrm{~g}$, respectively $(n=10)$. The body weights of cisplatin alone treated mice are significantly lower than that of both NS and therapeutic alliance treated mice $(p<0.01)$. This observation demonstrates that the therapeutic alliance is beneficial to preventing mice from platinum toxonosis related body damage. On the other hand, except absolute spleen weight (165.26 $31.65 \mathrm{mg}$ for NS receiving mice, $48.60 \pm 11.59 \mathrm{mg}$ for cisplatin alone receiving mice and $109.43 \pm 33.62 \mathrm{mg}$ for the therapeutic alliance mice) the absolute weights of all other organs of the therapeutic alliance mice approach that of NS receiving mice and are significantly higher than that of cisplatin alone receiving mice. Thus decrease in absolute organ weights will be indication of general weakening. This observation also demonstrates that the therapeutic alliance is beneficial to preventing mice from platinum toxonosis related organ damage. The relative weights of organ/body weight are summarized in Table 5. The data indicate that besides spleen/body weight all the others are at a comparable level. This means that cisplatin induced body emaciation is more serious than induced organ damage. Therefore some other damage should be also responsible for the body emaciation of cisplatin alone treated mice.
Table 5. Effects of the Therapeutic Alliance on Organ/Body Weight $^{\text {a }}$

\begin{tabular}{|c|c|c|c|}
\hline \multirow{2}{*}{ Group } & \multicolumn{3}{|c|}{ Organ/ Body Weight, \% } \\
\cline { 2 - 4 } & NS & Cp Alone & Cp + GID \\
\hline \hline Spleen & $0.54 \pm 0.10$ & $0.24 \pm 0.06^{\mathrm{b}}$ & $0.42 \pm 0.13$ \\
\hline Left kidney & $0.55 \pm 0.06$ & $0.64 \pm 0.09$ & $0.61 \pm 0.07$ \\
\hline Liver & $7.02 \pm 1.43$ & $6.45 \pm 0.65$ & $6.76 \pm 1.07$ \\
\hline Heart & $0.40 \pm 0.07$ & $0.35 \pm 0.09$ & $0.45 \pm 0.08$ \\
\hline Brain & $0.90 \pm 0.10$ & $0.81 \pm 0.14$ & $0.95 \pm 0.13$ \\
\hline Left femur & $0.22 \pm 0.05$ & $0.30 \pm 0.06$ & $0.26 \pm 0.06$ \\
\hline
\end{tabular}

a) NS (normal saline)=vehicle; $\mathrm{Cp}=$ cisplatin; $\mathrm{GID}=\mathrm{N}-(2,3,4,5,6$-pentahydroxylhex-1yl)-N-dithiocarbamate- $L$-isoleucine disodium; $\mathrm{n}=10$; b) Compare to NS and therapeutic alliance $\mathrm{p}<0.01$.

\subsection{Effect of GID on Survival of Cisplatin Receiving} Mice

As a serious result of cisplatin toxonosis related organ damage is death of mice. To evaluate the effect of the therapeutic alliance on cisplatin toxonosis induced death S180 mice were given a daily i.p injection of NS, the solution of $16.67 \mu \mathrm{mol} / \mathrm{kg}$ of cisplatin alone in $0.2 \mathrm{ml}$ of NS, or this solution plus the solution of $16.67 \mu \mathrm{mol} / \mathrm{kg}$ of GID in $0.2 \mathrm{ml}$ of NS for ten consecutive days. This was repeated for four times and their survival was recorded. From Table $\mathbf{6}$ it can be noticed that the total survival of both NS receiving mice and the therapeutic alliance mice was $100 \%$. On the other hand however the total survival of cisplatin alone receiving mice was only $40 \%$. This observation demonstrates that the therapeutic alliance is beneficial to increase the survival of cisplatin receiving mice.

Table 6. Effect of the Therapeutic Alliance on Survival ${ }^{\text {a }}$

\begin{tabular}{|c|c|c|c|}
\hline \multirow{2}{*}{ Group } & \multicolumn{3}{|c|}{ \% Survival on } \\
\cline { 2 - 4 } & $\mathbf{8}^{\text {th }} \mathbf{d a y}$ & $\mathbf{9}^{\text {th }}$ day & $\mathbf{1 0}^{\text {th }}$ day \\
\hline \hline NS & $100 \pm 0$ & $100 \pm 0$ & $100 \pm 0$ \\
\hline Cp alone & $80 \pm 7$ & $50 \pm 7$ & $40 \pm 10$ \\
\hline Cp + GID & $100 \pm 0^{\mathrm{b}}$ & $100 \pm 0^{\mathrm{b}}$ & $100 \pm 0^{\mathrm{b}}$ \\
\hline
\end{tabular}

a) NS (normal saline)=vehicle; $\mathrm{Cp}=$ cisplatin; GID $=\mathrm{N}-(2,3,4,5,6$-pentahydroxylhex-1yl)-N-dithiocarbamate- $L$-isoleucine disodium; Experimental number $=4$; b) Compared to NS $\mathrm{p}>0.05$ and to $\mathrm{Cp}$ alone $\mathrm{p}<0.001$.

\section{CONCLUSION}

As a dose-limiting factor cisplatin therapy-induced nephrotoxicity attracts a lot of interests and the reduction of the nephrotoxicity has been considered to be of clinically great importance. Based on a chelating mechanism this work provides a therapeutic alliance of GID. Using the suitable assays we found that GID based therapeutic alliance not only reduced the toxic effects but also supports the anti-tumor po- 
tency of cisplatin. Comparing to cisplatin alone, GID based therapeutic alliance greatly increased the urea quantity and urea platinum level of the treated mice. These may be considered as the path eliminating the platinum accumulation and reducing the organ damage of the mice receiving the therapeutic alliance. The facts that tumor platinum level of the mice receiving cisplatin alone equals to that of the mice receiving therapeutic alliance provide a sound basis for the latter. However, the reason of the enhanced antitumor activities of cisplatin by the therapeutic alliance remains to be elucidated.

\section{ACKNOWLEDGEMENTS}

This work was supported by Beijing Area Major Laboratory of Peptide and Small Molecular Drugs, the 973 Project of China (2006CB708501) and the National Natural Scientific Foundation of China (30672513).

$\begin{array}{ll}\text { ABBREVIATIONS } \\ \text { GID }= & \begin{array}{l}\mathrm{N}-(2,3,4,5,6-\text { Pentahydroxylhex-1-yl)-N- } \\ \text { dithiocarbamate- } L \text {-isoleucine Disodium }\end{array} \\ \mathrm{Cp} & \text { Cisplatin } \\ \mathrm{TLC}= & \text { Thin Layer Chromatography } \\ \text { MTT }= & 3 \text { - }[4,5 \text {-dimethylthiazol-2-yl]-2,5-diphenyl- } \\ & \text { tetrazolium bromide } \\ \text { DMSO = } & \text { Dimethyl sulfoxide } \\ \text { ESI-MS = } & \text { Electrospray Ionization Mass }\end{array}$

\section{REFERENCES}

[1] Giaccone G. Clinical perspectives on platinum resistance. Drugs 2000; 59 (Suppl 4): 9-17.

[2] Gonzalez VM, Fuertes MA, Alonso C, Perez JM. Is cisplatininduced cell death always produced by apoptosis? Mol Pharmacol 2001; 59: 657-663.

[3] Perez RP. Cellular and molecular determinants of cisplatin resistance. Eur J Cancer 1998; 34: 1535-1542.

[4] Dobyan DC, Levi J, Jacobs C, Kosek J, Weiner MW. Mechanism of cis-platinum nephrotoxicity. J Pharmacol Exp Ther 1980; 213: 551-556.

[5] Choie DD, Longnecker DS, Del Campo AA. Acute and chronic cisplatin nephropathy in rats. Lab Invest 1981; 44: 397-402.

[6] Fujieda M, Naruse K, Hamauzu T, et al. Effect of selenium on cisplatin-induced nephrotoxicity in rats. Nephron Exp Nephrol 2006;104: 112-122.

[7] Ciarimboli G, Ludwig T, Lang DF, et al. Cisplatin nephrotoxicity is critically mediated via the human organic cation transporter 2 . Am J Pathol 2005; 167: 1477-1484.

[8] Huang Q, Dunn RT, Jayadev S, et al. Assessment of cisplatininduced nephrotoxicity by microarray technology. Toxicol Sci 2001; 63: 196-207.

[9] Powis G, Hacker MP. The toxicity of anticancer drugs. Bergman Press, New York, 1990: 82-105.
[10] Ueda H, Sugiyama K, Yokota M, Matsuno K, Ezaki T. Reduction of cisplatin toxicity and lethality by sodium malate in mice. Biol Pharm Bull 1998; 21: 34-43.

[11] Francescato HD, Costa RS, Mafalda S, et al. Effect of oral selenium administration on cisplatin-induced nephrotoxicity in rats. Pharmacol Res 2001; 43: 77-82.

[12] De Martinis BS, Bianchi MD. Effect of vitamin C supplementation against cisplatin-induced toxicity and oxidative DNA damage in rats. Pharmacol Res 2001; 44: 317-320.

[13] Sueishi K, Mishima K, Makino K, et al. Protection by a radical scavenger edaravone against cisplatin-induced nephrotoxicity in rats. Eur J Pharmacol 2002; 451: 203-208.

[14] Rao M, Rao MNA. Protective effects of cystone, a polyherbal ayurvedic preparation, on cisplatin-induced renal toxicity in rats. J Ethnopharmacol 1998; 62: 1-6.

[15] Yilmaz HR, Iraz M, Sogut S, et al. The effects of erdosteine on the activities of some metabolic enzymes during cisplatin-induced nephrotoxicity in rats. Pharmacol Res 2004; 50: 287-290.

[16] Zhang JG, Lindup WE. Tiopronin protects against the nephrotoxicity of cisplatin in rat renal cortical slices in Vitro. Toxicol Appl Pharm 1996; 141: 425-433.

[17] Akaboshi M, Kawai K, Maki H, Akuta K, Ujeno Y, Miyahara T. The number of platinum atoms binding to DNA, RNA and protein molecules of Hela-cells treated with cisplatin at its mean lethal concentration. Jpn J Cancer Res 1992; 83: 522-526.

[18] Akaboshi M, Kawai K, Ujeno Y, Takada S, Miyahara T. Binding charateristics of (-)-(R)-2-aminomethylpyrrolidine(1,1-cyclo butanedicarboxylato)-2-platinum (II) to DNA, RNA and protein molecules in Hela-cells and its lethal effects-comparison with cisand trans-diamminedichloroplatinums (II). Jpn J Cancer Res 1994; 85: 106-111.

[19] Speelmans G, Staffhorst RWHM, Versluis K, Reedijk J, deKruijff B. Cisplatin complexes with phosphatidylserine in membranes. Biochemistry 1997; 36: 10545-10550.

[20] Jordan P, Carmo-Fonseca M. Molecular mechanisms involved in cisplatin cytotoxicity. Cell Mol Life Sci 2000; 57: 1229-1235.

[21] Barry MA, Benhke CA, Eastman A. Actavition of programmed cell-death (apoptosis) by cisplatin, other anticancer drugs,toxins and hyperthermia. Biochem Pharmacol 1990; 40: 2353-2362.

[22] Kruidering M, van de Water B, Zhan Y, et al. Cisplatin effects on F-actin and matrix proteins precede renal tubular cell detachment and apoptosis in vitro. Cell Death Differ 1998; 5: 601-614.

[23] Lippman AJ, Helson C, Helson L, Krakoff IH. Clinical trails of cisdiamminedichloroplatinum (NSC-119875). Cancer Chemother Rep Part 1 1973; 57: 191-200.

[24] Stark JJ, Howel SB. Nepherotoxicity of cisplatumn(II) dichlodoiamine. Clin Pharmacol Ther 1978; 23: 461-466.

[25] Wang C, Fang Y, Peng SQ. Synthesis of novel chelating agents and their effect on cadmium decoration. Chem Res Toxicol 1999; 12: 331-334.

[26] Wang C, Zhao M, Yang J, Li X, Peng SQ. Synthesis and evaluation of pentahydroxylhexyl-L- cysteine and its dimmer as chelating agents for cadmium or lead decorporation. Toxicol Appl Pharm 2004; 200: 229-236.

[27] Huo CX, Wang C, Zhao M, Peng SQ. Stereoselective synthesis of epimerically pure $\mathrm{N}$-(1-deoxy-D-fructos-1-yl)-L-amino acids and their effect on lead decorporation. Chem Res Toxicol 2004; 17: $1112-1120$.

[28] Wang YJ, Bi LR, Chen Y, et al. Design and synthesis of pentahydroxylhexylamino acids and their effect on lead decorporation. Chem Res Toxicol 2007; 20: 609-615. 